\title{
KEY INDICATORS OF CLUSTERIZATION POTENTIAL IN REGIONAL TOURISM
}

\author{
Maria GRITSAY \\ Omsk State Technical University, Faculty of, Department of Tourism, Hotel \\ and Restaurant Business, 644050, Russian Federation, Siberian Federal District, \\ Omsk Region, Omsk, Pr. Mira 11, e-mail: grihome@mail.ru \\ Evgenia KULAGINA* \\ Omsk State Technical University, Faculty of, Department of Tourism, hotel \\ and Restaurant Business, 644050, Russian Federation, Siberian Federal District, \\ Omsk Region, Omsk, Pr. Mira 11, e-mail: kevgeniya@inbox.ru

\section{Olga LUKINA} \\ Omsk State Technical University, Faculty of, Department of Tourism, Hotel \\ and Restaurant Business, 644050, Russian Federation, Siberian Federal District, \\ Omsk Region, Omsk, Pr. Mira 11, e-mail: lookina@list.ru

\section{Olga PRONCHEVA} \\ Omsk State Technical University, Faculty of, Department of Tourism, Hotel \\ and Restaurant Business, 644050, Russian Federation, Siberian Federal District, \\ Omsk Region, Omsk, Pr. Mira 11, e-mail: proncheva@bk.ru
}

\begin{abstract}
Citation: Gritsay, M., Kulagina, E., Lukina, O., \& Proncheva, O. (2018). KEY INDICATORS OF CLUSTERIZATION POTENTIAL IN REGIONAL TOURISM. GeoJournal of Tourism and Geosites, 22(2), 297-306. https://doi.org/10.30892/gtg.22201-288
\end{abstract}

\begin{abstract}
The research is aimed at proposing a system of clustering the tourist potential of a territory. The results are of interest for experts dealing with regional tourism development from the point of view of cluster approach. The theoretical part defines a tourist cluster as a network of the subjects of the regional tourist market, formed to promote the competitive product between the businesses and to preserve the vertical and horizontal inter-cluster competition. The documents determining the tourism development strategy in the Russian Federation are analyzed, and the results show a range of cluster initiative support policy distributions with the development of the regional tourism.
\end{abstract}

Key words: tourist cluster, clusterization potential, cluster development evaluation, the Omsk region, inter-cluster competition.

\footnotetext{
* Corresponding author
} 


\section{INTRODUCTION}

Multi-sidedness of the tourist interests develops the tourist industry on the territories with different nature and culture resources, infrastructure and services.

The development of the tourist industry together with the science-based tools guarantees to a certain degree the rational exploration of the socio-economic potential of a territory. Cluster approach (with its methodological basis lying in the works of R. Coase, M. Porter, M. Kastels, K. Prakhalad and V. Ramasvami, M. V. Vinokurova, etc.) is the ground for the tourism development in the Russian Federation. The development of the iteration process theory in the economy is connected with the works of R. Coase, devoted to the transaction expenses (Coase, 1960). In 1980s M. Porter carried out a number of studies and proved that the economic growth had selective and territorial spacious nature. The concentration centers of the economic subjects differed in low transactional expenses, innovation diffusion, and cooperative phenomena activation (Porter, 2010).

M. Kastels, an American sociologist, established a global distribution principle of communication development (Kastels, 2000). Moreover, the communicative networks of various organizations differ from the traditional cartels since they are connected with particular markets, goods, time periods, processes and with competition in diverse economic areas. One can observe the process when the network structures turn into a multi-division union, thus contributing into the complementation of the enterprise's functions and resources. K. Prakhalad and V. Ramasvami arrived at the conclusion that the strategic cooperation of the enterprises with the suppliers and competitors became an additional value of production (Prakhalad, 2006).

Integration processes of the production participants are considered to be a factor of economic development. Cluster (being an integration-network economic system) is recognized as an efficient tool for the development of production industry. The formation and development of the tourist clusters are specific in comparison with the clusters in industries and other production spheres. For example, asynchronous compilation, purchasing and consuming of a tourist product, the necessary congruence of tourist industry enterprises, and support given to the tourist services, as well as the participation of the related enterprises in the business processes, and other peculiarities of the tourist product development call for scientific clarifications of cluster approach application to the tourist development of the region.

There is a need for developing methodological grounds for cluster formation for the efficient implementation of the cluster initiatives in the sphere of regional tourism.

Therefore, the study and improvement of the tourist cluster testing mechanism is a rather burning methodological issue, with the most critical part being the choice of the clusterization potential indicators and their evaluation. Moreover, many experts, including L. Markov, Yu. Ryabchenyuk, Yu. Lavrikova, see the testing problems as the key ones in cluster policy implementation in Russia (Bogolyubov, 2013: Lavrikova, 2009; Markov, 2007; Yakunin et al., 2016). The notion of clusterization potential was introduced in the economic scientific theory to designate the possibility of uniting the enterprises from different industries and infrastructure organizations on the region's territory into an efficient production (or innovative) chain, as well as the possibility to combine their competitive advantages and to use these advantages to increase the competitiveness of the region (Vinokurova, 2006). E. Bergman and E. Feser systematized the methods to study the clusters in foreign scientific literature Bergman \& Feser, 1999).

The same problem is reflected in the studies of A. Prazdnichnykh in national science (Prazdnichnykh, 2006). The main methods to evaluate the clusterization potential of a tourist region are as follows: expert evaluation, matrix analysis (in particular, SWOTanalysis), the theory of graphs as a way to visualize the results, inter-industry balance 
analysis, and, finally, localization coefficients. However, the majority of the methods mentioned do not work for tourist cluster development from the very beginning.

\section{MATERIALS AND METHODS}

\section{Research methods}

The following methods were applied: theoretical (analysis; synthesis; specification; generalization; analogy; simulation; system and comprehensive approaches); diagnostic (questionnaire); empirical (analysis of the regulatory and methodological documentation; paired-comparison and numerical score as methods of expert evaluation); mathematical statistics and graphical representation of the results.

\section{Empirical grounds}

The Omsk Region as having a potential for the clusterization of regional tourism is taken to be the empirical ground of the research.

\section{Research stages}

The issue was analyzed at two stages:

- the first stage focused on the theoretical analysis of the existing methodological approaches to the understanding of the tourism clusters and to their studies in scientific works; the methodology was developed, and the subject area and the purpose of the research were articulated;

- $\quad$ the second stage concentrated on the development of the conceptual system of indicators for clusterization potential in a tourist region; the clusterization potential manifestation in the Omsk region was empirically studied with the help of expert evaluation methods, and the results obtained were processed and checked;

- $\quad$ theoretical and practical conclusions were specified at the third stage, and the obtained results were summarized and systematized.

\section{RESULTS}

\section{Structure and content of the indicator system for clusterization potential in a tourist region}

System approach helped develop a structural content model of key indicators for clusterization potential in a tourist region. The model includes the main and additional determinants of cluster development evaluation for a tourist region. The main determinants comprise beneficial geographic location of the region, availability of the tourist recreation resources (assets), and access to the tourist territories. The system of additional determinants includes actual demand on a regional tourist product, tourist interest to the region's territories, recognition of tourism and recreation in the region development strategy, businessmen and authorities interested in participating or at least in exploring this territory and developing a tourism business (Table 1).

Table 1. Consolidated indicators for the clusterization potential of a tourist region

\begin{tabular}{|l|c|}
\hline \multicolumn{1}{|c|}{ Sources of competitive advantages } & Expert evaluation \\
\hline 1. Favorable geographical location of the region & \multicolumn{1}{c|}{ yes/no } \\
\hline $\begin{array}{l}\text { 2. Availability and access to the tourist recreational resources } \\
\text { (assets) }\end{array}$ & $\begin{array}{l}\text { enough enough } \\
\text { accessible/inaccessible }\end{array}$ \\
\hline $\begin{array}{l}\text { 3. Demand on the region's tourist product in the domestic } \\
\text { (international) market }\end{array}$ & true/false \\
\hline 4. Seeing tourism as 'an advantage for the region's development' & true/false \\
\hline 5. High socio-economic importance of regional tourism & yes/no \\
\hline 6. Interest in cluster project implementation by the authorities & yes/no \\
\hline 7. Interest in cluster project implementation by businessmen & \\
\hline
\end{tabular}


The result of the structural content model functioning is the expressed potential of clusterization in a tourist region. Let us generally characterize the most critical combined indicators for clusterization potential of a tourist region. The advantage of geographical location can be evaluated with the following particular indicators: important transportation lines, climatic characteristics, hydrological resources, landscapes, etc.

The tourist recreation resources are relevantly evaluated by their types, while their accessibility, first of all, by the transport availability. Spheres for development declared in the Strategies and Development Programs are the indicators for the tourism to be considered as 'a pole of region development'. The indicators of socio-economic importance for the regional tourism are as follows: contribution of tourism industry into the development of the gross regional product, investment activity in the industry, population employment in the industry, living standards of people involved into the industry. The choice of the particular indicators is determined by the availability of the statistical information. The interests expressed by businessmen in cluster project implementation can be characterized by a degree of economic interests, including such indicators as possibility to increase the market value of cluster enterprise participants, receiving satisfactory (for a cluster participant) profit per invested capital, etc.

\section{Organization of empirical research}

The experts were chosen by the following criteria: at least a 10-year experience in the tourist industry; at least a 5-year experience in incoming and regional tourism; experience in designing and/or promoting the regional tourist product; participation in the business events in regional tourism development (conferences, round tables, business communicative platforms, etc.). The group of experts included 6 heads of the tourist firms and 20 managers of tourist firms, 5 employees of the Department in Tourism Development of the Ministry of Culture in the Omsk region, 6 representatives of the Culture Department of Administrations of the municipal districts of the Omsk region. The overall number of people involved was 31 . The clusterization possibility in a tourist region can be generally evaluated by the experts during the analysis and in selecting from various types of enterprises (Table 1). Positive answers will prove the high degree of clusterization potential for a tourist region, and vice versa. The suggested list of indicators is quite convenient since it can be altered depending on the details in clusterization potential evaluation. Methodology can be easily modified by introducing a score system and a descriptive score band, as well as the indicators of the specific importance for the sources of the competitive advantages, which will account for the peculiarities of the particular region. For this purpose the work of experts was organized in two stages.

The purpose of the first stage was to evaluate the importance of the given indicators; the matrix of pair-wise indicator comparison served to be a tool here. Each expert stuck to the following rating band in filling in the matrix: 2 scores if the compared indicator was important; 1 score in case of equal importance; o score if the compared indicator was deemed less important. The obtained data identified the total score of importance for each indicator evaluated by each expert. The summary of the data gave the mean total score for the indicator importance by the formula of arithmetical mean. Finally, the total mean score of indicator importance was transformed into the relative value through its division on a sum of the same evaluations at the indicator combination.

The purpose of the second stage was to evaluate the availability (lack) of the evaluated indicator. Rating band is given in Table 2.

Summarizing the data, average expert assessment for the availability (lack) of the evaluated indicator in scores is defined with the formula of arithmetic mean.

Empirical introduction of the model for evaluating the clusterization potential of a tourist region (a case of the Omsk region) 
Let us show the possible implementation for the suggested indicators in evaluating the clusterization potential for the Omsk region's tourist industry.

Table 2. Rating band

\begin{tabular}{|l|c|c|c|}
\hline \multicolumn{1}{|c|}{$\begin{array}{c}\text { Source of competitive } \\
\text { advantages }\end{array}$} & o & 1 & 2 \\
\cline { 2 - 4 } $\begin{array}{l}\text { 1. Favorable geographical } \\
\text { location of the region }\end{array}$ & not available & insufficiently available & available \\
\hline $\begin{array}{l}\text { 2. Availability of tourist } \\
\text { recreational resources }\end{array}$ & not available & not enough & enough \\
\hline $\begin{array}{l}\text { 3. Access of the tourist } \\
\text { recreational resources (assets) }\end{array}$ & not accessible & partially accessible & accessible \\
\hline $\begin{array}{l}\text { 4. Demand on the region's } \\
\text { tourist product in the domestic } \\
\text { (international) market }\end{array}$ & not available & minor & high \\
\hline $\begin{array}{l}\text { 5. Seeing tourism as 'an } \\
\text { advantage in the region's } \\
\text { development' }\end{array}$ & statement is false & $\begin{array}{c}\text { statement is } \\
\text { partially true }\end{array}$ & statement is true \\
\hline $\begin{array}{l}\text { 6. High socio-economic } \\
\text { importance of regional tourism }\end{array}$ & statement is false & $\begin{array}{l}\text { statement is } \\
\text { partially true }\end{array}$ & statement is true \\
\hline $\begin{array}{l}\text { 7. Interest expressed by the } \\
\text { authorities in cluster project } \\
\text { implementation }\end{array}$ & no interest & $\begin{array}{c}\text { interested, but of } \\
\text { declarative nature }\end{array}$ & highly interested \\
\hline $\begin{array}{l}\text { 8. Interest expressed by } \\
\text { businessmen in cluster } \\
\text { project implementation }\end{array}$ & no interest & available & highly interested \\
\hline
\end{tabular}

1. Geographical location of the Omsk region. The Omsk region is a subject in the Siberian Federal district. It has a very favorable geographical location and a developed network of highways, railways and seaways (the Irtysh river), international and Russian airlines. The Omsk region borders the Kazakhstan Republic; the territory of the region occupies $600 \mathrm{~km}$ from north to south and $300 \mathrm{~km}$ from east to west.

2. Availability and access to the tourist recreational resources. The Omsk region is characterized by high tourist recreation potential which is determined by a vast territory, rich historical and cultural heritage and the impressive natural diversity. There are 33 natural sites characterizing the tourist attractiveness of the region (including the specially protected natural sites of the federal and regional importance). The region's territory holds 10 sites of the cultural heritage of federal importance; 42 museums and 10 theaters work there as well. Tourist recreation resources contribute to the development of such types of tourism as cultural, educational, rural, ethnic, ecological, as well as active tourism (trekking and water trips).

3. Demand on the region's tourist product in the domestic (international) market. Federal Tourism Agency puts the Omsk region into Top 30 regions of Russia (24th place) where the number of tourists is more than 100 thousand annually. However, it should be noted that outbound tourism prevails in the Omsk region, as well as in most other regions in Russia.

4. Seeing tourism as a 'growth zone', a 'pole' of region development. Documents on tourism development in the Omsk region specified the promising territories: Tarskiy, Muromtsevkiy, Bolsherechenskiy, Odesskiy, Tyukalinskiy and Bolsheukovskiy districts. These tourist subcluster territories in the Omsk region were defined by the projectpurpose development of the regional tourist industry. 
5. Socio-economic importance of regional tourism. The analysis of the statistical data for the previous five years shows that in the overall amount of the chargeable services the specific amount of the tourist, health services and hotel services has a fixed value (about $4.7 \%$ ). As for the tourist services, the analyzed period shows a stable trend to increase the physical implementation amount. Overall, for the studied period an average yearly growth rate of the physical amount of tourist service sale was $5.2 \%$, which contributed to the increase of the tourist service share in the overall amount of the chargeable services for the population from 2.2 to $2.4 \%$. Despite the increase in the consumer spending, the expenditure on rest and travel (that is, share of the tourism sphere in the consumer spending) remains rather low - less than $1 \%$. In the Omsk region (compared with other regions of the Siberian Federal District) the number of the sold tours and the increase in their price share in the gross domestic product is quite stable, ranging from $0.46 \%$ to $0.57 \%$. In Russia the share of the tourism profit in GDP is less than $1 \%$, while in the EU countries it is about $5.5 \%$ [18]. Analyzing the population employment in the industry it should be noted that in the Russian economy about 4 working places out of 1000 are in the tourism sphere (to be compared with every 15th place in the world economy). As for the Omsk region, the figure is lower than the country's average. For instance, by the end of the analyzed period the average annual employment in tourism in the Omsk region was 3,395 people or $0.36 \%$ of the average employment $\mathrm{n}$ the whole, and this indicator is displaying a tendency to grow. As for the investment attractiveness, the most capital-intensive is the hotel business.

The analysis of the statistical data for the previous five years shows the investment activity of the enterprises such as hotels and restaurants (not taking small businesses into account) in the Omsk region is low in comparison with the Siberian Federal District and Russia on the whole. Despite the fact that in 2012 the Omsk region was characterized by higher (with respect to the index of physical investment volume) level of investment activity than the Siberian Federal District and Russia on the whole, the last five years showed a stable trend to reduce the investments into the main capital. The negative effect of the situation is that the depreciation of fixed capital by type of economic activity (hotels and restaurants) at the end of the period under review exceeded the threshold level of $50 \%$ and amounted to $52.4 \%$. It is quite reasonable to characterize the living standards of the population employed in the industry on the basis of the statistical information, nominal and actual salaries and the minimum wage in the region.

The analysis of the nominal monthly (average) salary of the tourism employees for the previous five years reveals that it is lower than that of region on the whole and not more than two or three times as large as the minimum subsistence level. Tourism is characterized by the significant differentiation of the employees in the monthly salary level. For example, the monthly salary in hotels and tourist agencies is higher than in other places of temporary residence. The average annual salary growth for the hotels' employees was $\mathbf{2 8 . 8} \%$ (while in the region for the same period this number increased by $14 \%$ ), yet for the tourist agencies it was lower $-12.9 \%$. At the same time, the monthly salary exceeded the minimum level not more than three times and was significantly less than the average salary in the region (for example, in 2012 the gap was almost $40 \%$ ). It should be noted that the Omsk region is characterized by an unchanged low salary level in the Siberian Federal District for the analyzed period. To sum up, it should be noted that comparing the relative socio-economic indicators of the Omsk region, the Siberian Federal District and Russia gives an idea of rather high socio-economic importance of tourism in the Omsk region.

Despite the fact that the tourism sphere in the Omsk region is developing at a stable dynamic pace, the comparative analysis of the indicators shows the significant delay in the region's industry development by such indicators as investment 
attractiveness and income level of the employed population. Minor delay can also be observed in implementing such function as employment; a very small share of the domestic and incoming tourism in tourist products is also a negative factor.

6. Interests expressed by the authorities in cluster project implementation. It should be noted that the authorities in the Omsk region are interested in cluster project implementation. The 2014-2020 Culture and Tourism Development, a state program of the Omsk region, specifies the necessity to develop the tourism through clusterization of the economic relations among the tourist market subjects. Moreover, one should point out that the authorities regularly implement measures aimed at supporting and developing the cluster initiatives to establish the communicative links between the enterprises of the regional tourist industry (seminars, meetings, business sites, etc.).

Integral evaluation of the regional clusterization potential through the application of expert evaluation method is given in Table 3 .

Table 3. Consolidated indicators for the clusterization potential of regional tourism (the Omsk region)

\begin{tabular}{|l|c|c|c|}
\hline \multicolumn{1}{|c|}{ Clusterization potential indicator } & Importance & $\begin{array}{c}\text { Expert evaluation of the } \\
\text { indicator availability } \\
\text { (average score) }\end{array}$ & $\begin{array}{c}\text { Weighted } \\
\text { average expert } \\
\text { evaluation }\end{array}$ \\
\hline $\begin{array}{l}\text { 1. Favorable geographical location of the } \\
\text { region }\end{array}$ & 0.062 & 2.774 & 0.172 \\
\hline $\begin{array}{l}\text { 2. Availability of tourist recreational } \\
\text { resources }\end{array}$ & 0.176 & 2.774 & 0.488 \\
\hline $\begin{array}{l}\text { 3. Access of the tourist recreational } \\
\text { resources (assets) }\end{array}$ & 0.147 & 2.0 & 0.294 \\
\hline $\begin{array}{l}\text { 4. Demand on the region's tourist product } \\
\text { in the domestic (international) market }\end{array}$ & 0.179 & 2.742 & 0.491 \\
\hline $\begin{array}{l}\text { 5. Seeing tourism as 'an advantage in the } \\
\text { region's development' }\end{array}$ & 0.069 & 2.226 & 0.153 \\
\hline $\begin{array}{l}\text { 6. High socio-economic importance of } \\
\text { regional tourism }\end{array}$ & 0.083 & 2.226 & 0.185 \\
\hline $\begin{array}{l}\text { 7. Interests in cluster project } \\
\text { implementation from the authorities }\end{array}$ & 0.132 & 2.258 & 0.298 \\
\hline $\begin{array}{l}\text { 8. Interests in cluster project } \\
\text { implementation from businessmen }\end{array}$ & 0.152 & 2.0 & 0.304 \\
\hline \multicolumn{1}{|c|}{ Total } & 1.000 & $\mathrm{x}$ & 2.385 \\
\hline
\end{tabular}

Summarizing the data given in Table 3 one should characterize the degree of clusterization potential availability in the regional tourism in the Omsk region as a rather high one. The total score is $79.5 \%$ of the maximum. The implementation of the designed model enables one to monitor the clusterization potential for a tourist region with due regard to the peculiarities of the tourist cluster development.

\section{DISCUSSIONS}

Theoretical analysis of the existing methodological approaches to understanding tourist clusters, and clusters study in scientific literature lets the authors of the paper conclude that the notion of 'tourist cluster' is very controversial, despite the cluster approach recognition as the main one in developing regional tourism.

According to the normative documents, a tourist cluster that can receive state registration is '... a set of tourist and recreational special economic zones established by a decision of the Government of the Russian Federation and located on one or several 
sections of the territory of the constituent entities of the Russian Federation and municipal entities designated by the Government of the Russian Federation. The managing company of the tourist cluster is a legal entity in the form of a JSC established on the principles of state-private partnership, which, under the decision of the Government of the Russian Federation, can be delegated separate powers to manage tourist and recreational special economic zones included in the tourist cluster (Porter, 2010). This type of tourist clusters is mainly developed through the initiatives from the state bodies and is one of the components in the strategic development policy of regional economy. For the bottom-up initiatives the tourist cluster associations are considered to be '...the societies of different enterprises and organizations over a particular territory which are directly or indirectly connected with providing the tourist services' (Yevplanov, 2011). A. A. Bogomolov defines a tourist cluster as a group of companies: tour operators, tour agents, hospitality industry, transport services providers, trading firms and scientific research institutes dealing with the problems of regional tourism development (Kraynik, 2009). E. G. Karpova believes the tourist cluster to be a set of business processes in the development and implementation of a tourist product (Karpova, 2012). In her definitions A. Osminkina specifically considers the location (Osminkina, 2009).

O. M. Kotova also grounds her definitions of a tourist cluster on the geographical proximity ('...a concentrated group of interconnected competing, but jointly working companies and organizations in recreation and tourist industry in a particular recreational (tourist) region of the country') (Kotova, 2012). E.A. Melekhina stands apart in her definition of a tourist cluster; she believes a route territory organization to be its the main feature. A route characterized by a particular intensity of tourist flow connects the tourist infrastructure objects which contribute to the cluster development (Melekhina, 2012). E. G. Kropinova and A.V. Mitrofanova define cluster as a comprehensive system comprising 'local groups of manufacturing enterprises in the tourist service and related industries, different non-manufacturing organizations where joint efforts are combined to satisfy the recreational needs' (Kropinova, 2011).

It is necessary to clarify some points in the definition of this term to mitigate the controversies. Considering the peculiarities of the making, distribution and consumption of a tourist product we believe that a tourist cluster is a network union of the subjects of the regional tourist market, formed to create and promote the competitive tourist product with the developed system of communicative connections between the participants of the business processes and preserving the mechanisms of the vertical and horizontal intercluster competition. To study the implementation of cluster policy in Russian tourism, the analysis of the strategic development programs of the subjects of the Russian Federation was conducted. The obtained data shows that more than fifty subjects of the Russian Federation apply the cluster approach in the development of the tourist regional branch (Maevskiy, 2014). Comparing the prevalence of tourist cluster initiatives with other industries, it should be noted that, according to the number of forming or declared clusters, the tourist industry occupies the second place after agriculture.

This popularity in Russia can be explained by multi-functional possibilities in the tourist sphere: economic importance, social and cultural roles, educational and recreational importance, etc. In 2014 a list of the planned subsidized tourist clusters was updated which included 69 projects (Russian Federal Law, 2014).

The analysis of the thematic spheres in tourist cluster projects subsidized by the state (Figure 1) reveals that the majority of the projects are connected with the development of the cultural educational and health improvement tourism.

The majority of the cluster projects supported by the state subsidies are mainly located on the territories of the Siberian (26\%), Central (23\%) and North-Western (16\%) 
Federal Districts. Despite an active regional policy in implementing the cluster approach, the problem of identifying a tourist cluster still stands. The development of the regional tourist clusters is peculiar, since sometimes the cluster develops from the very beginning despite the availability of the tourist assets in the region. The main theories of the cluster formation (for instance, the theory of E. Bergman and E. Fezer and the studies of A. Prazdnichnykh) state that the enterprises united by any production or by the common sphere of activity exist and function in the region. Therefore, the authors suggest a system of indicators to evaluate the clusterization potential for a regional tourism, including the main and additional determinants of the cluster development evaluation (Table 1).

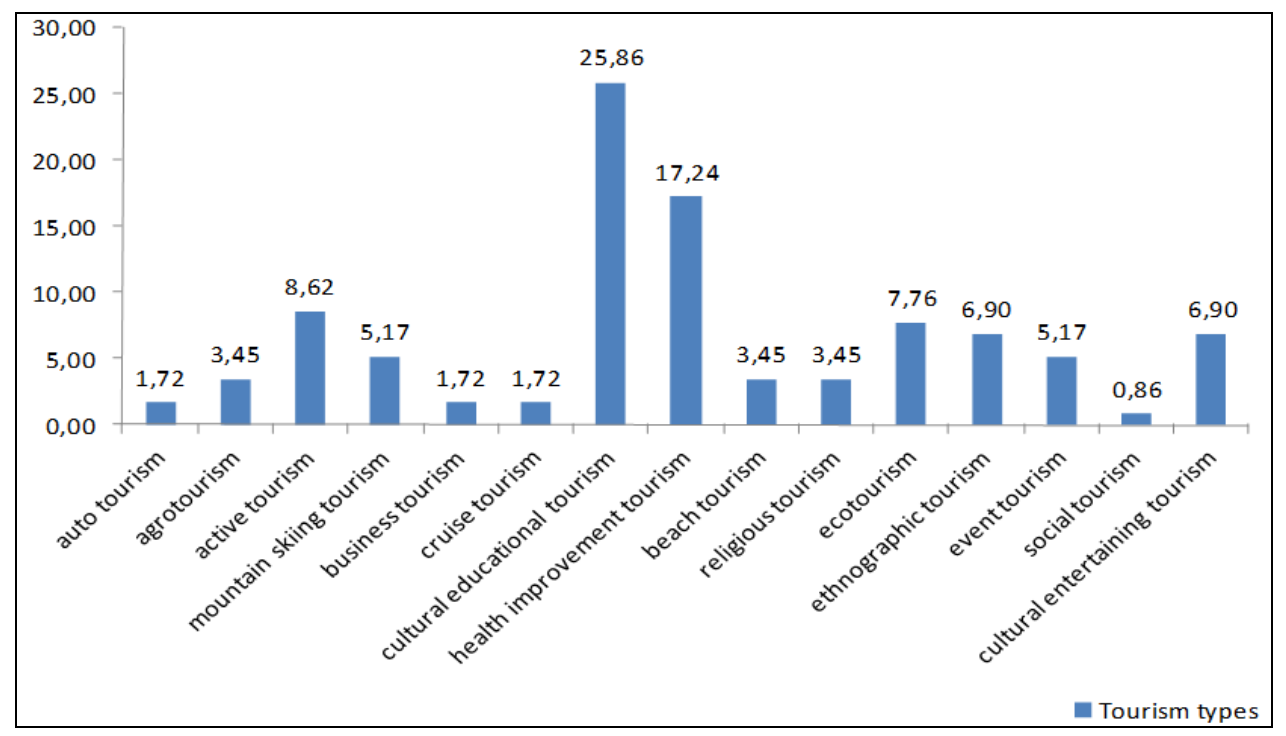

Figure 1. Structure of the implemented cluster initiatives in the subjects of the Russian Federation by tourism types, \%

The main methods to evaluate the clusterization potential of a tourist region are as follows: expert evaluation, matrix analysis (in particular, SWOT-analysis), and the theory of graphs as a way to visualize the results. E. Bergman, E. Feser and other scientists suggested a method of inter-industry balance analysis to evaluate the possibility of tourist cluster development. This is not applicable since the core of this cluster is mainly represented by the infrastructure enterprises united by the common sphere of activity. In case of tourist cluster development from the very beginning the widely spread localization coefficients are not valid here. We believe that expert evaluation method is one the most adequate for the overall evaluation of clusterization possibility. This method is cost and time efficient.

\section{CONCLUSION}

Summarizing the research is should be noted that a list of indicators for the clusterization potential in a tourist region can be extended to include the indicator of availability and concentration degree of the competitive enterprises in different sectors connected with tourist services, which are able to constitute 'the core of the cluster'.

The analyzed approach to define a tourist cluster will contribute to eliminating such problems in its identification as the underdevelopment of measuring parameter system, etc. Thus, the results of the conducted research complement the methodological basis for the cluster approach applied to the tourist industry development. 


\section{REFERENCES}

Bergman E., \& Feser E. (1999). Industrial and Regional Clusters: Concepts and Comparative Applications. Regional Research Institute, West Virginia University,

Bogolyubov, V. S. (2013). Ekonomika turizma [Economy of Tourism] V.S. Bogolyubov, V.P. Orlovskaya. - M., Akademiya.

Coase, Ronald, H. (1960). The Problem of Social Cost. Journal of Law and Economics, vol.3, p. 1-44.

Karpova, E., G. (2012). Razvitie sfery turistskikh uslug krupnogo turistskogo tsentra na osnove klasternogo podkhoda [Development of Tourist Service Sphere in a Large Tourist Center with Cluster Approach] avtoref. dis. ... kand. ekon. nauk. E.G. Karpova. - SPbGIEU. SPb.

Kastels, M. (2000). Informatsionnaya epokha. Ekonomika, obshchestvo i kultura [Information Epoch. Economy, Society and Culture] M. Kastels. - M. Izd-vo GU - Vysshaya shkola ekonomiki, p. 165

Kotova, O., M. (2012). Turistsko-rekreatsionnyy klaster: ponyatie i sushchnost [Tourist Recreation Cluster: Notion and Nature] O.M. Kotova. Kurortno-rekreatsionnyy kompleks $v$ sisteme regionalnogo razvitiya: innovatsionnye podkhody. vol.1, p. 133-137.

Kraynik, A. (2009). Turisticheskiy klaster regiona kak forma sotsialnogo dialoga: upravlencheskiy aspect [Region Tourist Cluster as a Form of Social Dialogue: Management Aspect] A. Kraynik, M. Bil, Nauchnyy vestnik 'Demokraticheskoe upravlenie', vol.4, p. 43-54.

Kropinova, E., G. (2011). Regionalnyy turistskiy klaster kak turistsko-rekreatsionnaya sistema regionalnogo urovnya. [Regional Tourist Cluster As a Tourist Recreation System at Regional Level] E.G. Kropinova, A.V. Mitrofanova. Regionalnye issledovaniya. vol. 1 (31), p. 40-49.

Lavrikova, Yu., G. (2009). Klastery kak rynochnyy institut prostranstvennogo razvitiya ekonomiki regiona [Clusters as Market Institute of Spacious Development of Regional Economy]: diss. ... doktora ekonom. nauk/ Yu.G. Lavrikova. - Yekaterinburg.

Maevskiy, D., P. (2014). Analiz razvitiya klasterizatsii otrasley ekonomiki v subektakh rossiyskoy federatsii [Analysis of Clusterization Development of Economy Spheres in the Subjects of the Russian Federation] D. P. Maevskiy, E.V. Kulagina, M. A. Gritsay, V mire nauchnykh otkrytiy. vol.11.4 (59), p. 1540-1555.

Markov, L., (2007), Problemy realizatsii klasternoy politiki [Problems of Cluster Policy Implementation] L. Markov, Nauchnyy ekspert. vol.4, p. 20-31.

Melekhina, Ye., A. (2012). Sovremennaya definitsiya ponyatiya «klaster» i podkhody k formalizatsii etogo yavleniya na primere «turistskogo klastera» [Modern Definition of Cluster and Approaches to Formalizing this Phenomenon Exemplified by a Tourist Cluster] Ye.A. Melekhina, Problemy sovremennoy nauki i obrazovaniya. vol.2 (12), p. 66-68.

Osminkina, A. (2009). Issledovanie vozmozhnostey sozdaniya informatsionno-analiticheskikh modeley dlya postroeniya i upravleniya turistskimi klasterami (na primere Vladimirskoy oblasti) [Study of Possibilities to Create Information Analytical Models to Construct and Manage Tourist Clusters (the case of the Vladimir Region] A. Osminkina, Algoritmy, metody i sistemy obrabotki dannykh. vol.1, p. 109-114.

Porter, M. (2010). Konkurentsiya [Competition] M. Porter. - M. Vilyams.

Prakhalad, K. K. (2006). Budushchee konkurentsii. Sozdanie unikalnoy tsennosti vmeste s potrebitelyami [Future of Competition. Formation of Unique Value Together with the Consumers] K.K. Prakhalad, V. Ramasvami. - M. Olimp-biznes.

Prazdnichnykh A. (2006). Opredelenie territorialnykh zon potentsialnogo razvitiya clasterov v Rossiiskoi Federatsii [Identification of Territorial Zones of Cluster Potential Development in the Russian Federation] A. Prazdnichnykh- M. ANKh.

Vinokurova, M., V. (2006). Konkurentosposobnost i potentsial klasterizatsii otrasley ekonomiki Irkutskoy oblasti [Competitiveness and Clusterization Potential of Economy Industries in the Irkutsk Region] M.V. Vinokurova, EKO. vol.12, p. 73-92.

Yakunin V., N., Ovsyannikov V., P., Yamashev V., M., Nikitina N., V., Skornichenko N., N., \& Alexeyeva N., D. (2016). Tourism Industry: Problems and Prospects of Development. International Journal of Humanities and Cultural Studies. June 2016 Special Issue, p. 995-1004.

Yevplanov, A. (2011). Dogovorilis o termine. Deputaty vyyasnili, chto takoe turisticheskiy klaster [Agreed on the Term. MPs Found Out What A Tourist Cluster Is] A. Yevplanov, Rossiyskaya Biznes-gazeta. vol. 800 (18).

*** Order of the Ministry of Culture of the Russian Federation. Federal Tourism Agency of 21 July 2014 № 245Пр-14 «On Approval of a List of Investment Projects Included by the Coordination Council into the List of Measures of the Federal Purposeful Program 'Development of Domestic and Incoming Tourism in the Russian Federation (2011-2018)" // Official website of the Federal Tourism Agency of Ministry of Culture of the Russian Federation. http:// www.russiatourism.ru/ (date of reference: 14.08.2015).

Submitted:

25.07.2017
Revised:

16.04.2018
Accepted and published online 19.04.2018 